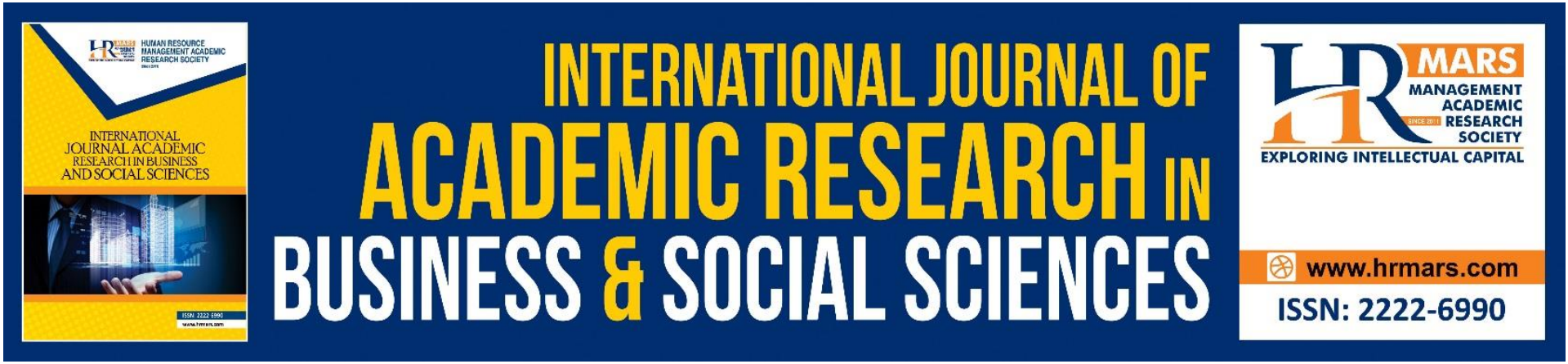

\title{
A Social Littering Attitude among University Students in Malaysia
}

Mas'udah Asmui, Suhanom Mohd Zaki, Musramaini Mustapha, Mohd Faizal Azrul Azwan Muhamed@Che Harun, Saifudin Razali

To Link this Article: http://dx.doi.org/10.6007/IJARBSS/v11-i11/11350～DOI:10.6007/IJARBSS/v11-i11/11350

Received: 04 September 2021, Revised: 06 October 2021, Accepted: 25 October 2021

Published Online: 11 November 2021

In-Text Citation: (Asmui et al., 2021)

To Cite this Article: Asmui, M., Zaki, S. M., Mustapha, M., Harun, M. F. A. A. M., \& Razali, S. (2021). A Social Littering Attitude among University Students in Malaysia. International Journal of Academic Research in Business and Social Sciences, 11(11), $951-962$.

Copyright: @ 2021 The Author(s)

Published by Human Resource Management Academic Research Society (www.hrmars.com)

This article is published under the Creative Commons Attribution (CC BY 4.0) license. Anyone may reproduce, distribute, translate and create derivative works of this article (for both commercial and non-commercial purposes), subject to full attribution to the original publication and authors. The full terms of this license may be seen at: http://creativecommons.org/licences/by/4.0/legalcode

Vol. 11, No. 11, 2021, Pg. 951 - 962

Full Terms \& Conditions of access and use can be found at http://hrmars.com/index.php/pages/detail/publication-ethics 




\title{
A Social Littering Attitude among University Students in Malaysia
}

\section{Mas'udah Asmui, Suhanom Mohd Zaki, Musramaini Mustapha, Mohd Faizal Azrul Azwan Muhamed@Che Harun, Saifudin Razali}

Faculty of Business and Management, Universiti of Teknologi MARA, Pahang Branch, 26400 Jengka, Pahang, Malaysia, Faculty of Electrical and Electronic Engineering Technology,

Universiti Malaysia Pahang, 26600 Pekan, Pahang, Malaysia

Email:mas_as@uitm.edu.my, suhanom@uitm.edu.my,musra_08@uitm.edu.my, faizalazrul@uitm.edu.my, saifudin@ump.edu.my

\begin{abstract}
Littering has been a long-term issue since ages ago. It is a recurring world wide problem, mainly in the fast-growing cities and towns. This problem has caused various negative effects on the environment such as unpleasant view, harmful to people and animals and causing bad odour. Adolescences are future generation in which will be expected to solve this long-term littering issue. Besides providing proper education, it can promisingly be eliminated by integrating the elements of religiosity, pro-environmental behaviour, and social ethics. A number of 139 university students in semester one had participated this study survey. Statistical analyses using descriptive statistics revealed that university students have moderately high littering attitudes. Their participation and desire to participate in garbage disposal operations, as well as to engage litters not to litter, were still relatively low, despite their own ethics and worry about waste problems increasing. Some students, on the other hand, agreed that litterers would throw trash next to a full litter bin if there was no empty litter bin nearby. These studies revealed that they have a lower social pro-environmental, earth preservation, and conservation attitude. As a result, while developing social marketing interventions to encourage anti-littering behaviour, social marketers should pay special attention to subjective norms and attitudes.
\end{abstract}

Keywords: Social Littering Attitude, University Students, Malaysia

\section{Introduction}

Littering is defined as disposing rubbish carelessly, that includes a wide range of waste, as smallest as the cigarette butt, to the largest item such as abandoned vehicle (Hansmann and Scholz, 2003). It is common to see coffee cups, soda cans, plastic bags and numerous other things being littered along the road and dumped at an empty corner. These littering activities are resulted from insensitivity of human beings towards maintaining the environment. Individuals with certain desirable personal traits and unfavorable attitudes towards littering will have greater tendencies to participate in pro-environmental behaviours (Ojedokun, 
2011). For this matter, several countries in Asia, including Malaysia had put a concern on producing more research on littering behaviour and attitude. In 2020, Malaysia had estimated 30,000 tons of solid waste generation as compared to 2012, where Malaysian generated 33,000 tons solid waste per day (Mokhtar, 2013). This alarming figure has raised a concern on the needs of alternative waste management methods such as raising awareness campaigns among Malaysian citizens and environmental education programs at schools and universities.

Littering not only endangers and harms our environment, but it also serves social, economic, political, institutional and environmental issues. It has become one of the most pressing issues confronting authorities and residents. Littering problems are not uncommon in higher education institutions. Prior studies have shown that young people have a lower social proenvironmental, earth preservation, and conservation attitude. Campus students litter as well (Asmui et al., 2019), and studying garbage disposal attitudes among them is important because this population is the world's largest, and they are the primary sources of littering. Furthermore, they are our future leaders who will be in charge of regulating the quality of environmental hygiene. As a result, we must take proactive steps to shape social littering attitudes among the younger generation. Hence, this study has generated two research objectives, which are, 1) to determine the level of attitudes towards littering among university students, and 2) to examine the students' attitude towards littering. By determining the level of littering among the university students and what is their attitude towards littering, this study can provide input to universities and governments on what is a decisive practice or remedy. Besides affecting the students' growth of social lives, a hygienic environment also discreetly contributes to enhancing their cognitive development. It is also important to cultivate the anti-littering attitude among tertiary students to ensure the sustainability of the environment.

\section{Literature Review}

There is almost no existing literature that was found related to littering behaviour in Egypt and how to reduce its environmental impact (Torky, 2017). However, many empirical studies on littering behavior are increasingly produced in several countries in Asia such as Jordan, Iran, Japan and Singapore (Ibrahim et al., 2021), as well as Malaysia. Although, many studies had focused on school students and environmental topics (Bradley et al., 1999; Asmuni et al., 2012), there were very few that included university students as a group per se (VicenteMolina et al., 2013). Vicente-Molina et al (2013) further explained that some of these studies emphasised on identifying the influence of a few variables on the behavioural intentions of business students (Cordano et al., 2010), the environmental beliefs of students majoring in different areas (Ewert and Baker, 2001), the level of general environmental concern of students (Oguz et al., 2010) or simply use university students to define a general consumer profile (Synodinos, 1990).

Furthermore, there is not much that is said about social littering in particular. However, throwing trash next to a full litter bin even if there was no empty litter bin nearby, including students' desire to participate in garbage disposal operations, as well as to change litters not to litter, are mostly talked about. In a study examining the role of Islamic environmental ethics in pro-environmental behavior in Egypt, Rice (2006) found a link between religiosity and pro-environmental behaviors and argued that focusing on personal ethics is effective in 
countries where environmental laws are not adequately enforced (Torky, 2017). Personal ethics refers to the ethics with which a person identifies in relation to people and situations encountered in daily life. Personal ethics are developed through teaching from parents, relatives, and friends, as well as personal experiences. In contrast, social ethics demonstrate individual moralities shaped by social contexts, which include moral areas of social frameworks, structures, concerns, and societies. Social littering is an individual's concerns on the effect of littering towards societies' lives that pertain to social, economic and political aspects. It is also shaped by individual moralities and accountabilities towards nature preserves. Previous research has focused on awareness campaigns, the lack of nearby trash cans, and the demographic association of profiles with trash-throwing attitudes (Arafat et al., 2007; Torky, 2017; Asmui et al., 2016, Asmui et al, 2016; Asmui et al, 2019). Carmi (2019), has studied social distress, littering and nature conservation among the Jisr A-Zarka residents. He collected their perceptions of litter and littering practices and found that littering and waste accumulation are surface indicators of profound underlying social, economic and political constraints, problems and distresses. And Carmi (2019) concluded that the issues must be considered as an integrated context and addressed when designing litter-reducing interventions.

Estebsari, Taghdisi, Kandi, and Hosseini (2017) discovered that students had a positive effect on their parents' participation in recycling at the source. This study investigated the effects of recycling educator students on the operation of parents in waste separation. After the education program, the highest score was 58 percent for separation of recyclable waste from non-recyclable waste. Another approach to get students participation in garbage disposal operations is to propose that environmental sustainability education be integrated into schools at all levels within developing countries in order to bridge the knowledge gap between the youth and older people in Solid Waste Management (SWM) (Debrah, Vidal, and Dinis, 2021). For that matter, the environmental attitudes of young people must be critical as they ultimately play a direct role in providing knowledge-based solutions to emerging environmental problems (Sultana et al., 2017; Janmaimool et al., 2019; Debrah et al., 2021). Besides, children should be taught with a positive attitude toward SWM, through environmental education, which will teach children to respect the environment and its resources (Debrah et al., 2021).

According to Chaerunnissa et al (2020), the issue of proper waste management in Indonesia has not been just a government concern; rather, it is a shared responsibility that includes all citizens and households, some of whom may lack awareness of public waste management. All citizens including university students are recommended to engage in community works such as volunteering to clean a littered environment and signing up for environmental club membership so that they have a sense of belongings in nature preserves. Litter has the potential to cause harm to human health, safety, welfare, as well as the environment (Ahmad, 2021). The attitude of Malaysians who easily leave the rubbish on the chair and throw it into the drainage without thinking about the effects of the action will damage the beauty of the environment (Yatim, 2020). Anti-littering practises are increasingly being publicised through the mass and social media, and environmental education is already being taught to Malaysian schoolchildren. Even higher education institutions also see anti-littering practices as something very important because they are aware that a clean environment has an influence on students' learning performance (Lizzio et al., 2002; Ibrahim et al., 2021). Bautista (2019) 
revealed that the students are aware of solid waste management. Majority of them were aware of the policies and management of solid waste management but moderately not aware of their role as students in the execution of solid waste management. The students also have good practices in solid waste management in terms of properly disposing of, recycling, and reusing but relatively low practice proper segregation and reducing.

\section{Research Methodology and Data Procedures}

A quantitative methodology was adopted in this research. The data was obtained from students in higher learning institutions at Universiti Teknologi MARA (UiTM) Pahang Branch via online survey method. 139 of Semester One Diploma in Office Management and Technology (BA118) students responded to the questionnaire. A 5-point Likert-scale format range from 1 (strongly disagree) to 5(strongly agree) was used to measure the variables in Part A and demographic profile of respondents was retrieved in Part B. The data was analyzed by using IBM-SPSS 28.0 software for descriptive statistics tools. The questionnaire questions were adopted from Ojedokun (2015), who developed a littering attitude scale (LAS) to assess littering attitudes. The reliability analysis measured variable littering attitude and it was poor reliability (Table 1) due to seven negative items that were not reversed code.

Table 1: Reliability Analysis

\begin{tabular}{|c|c|c|}
\hline Variable & $\begin{array}{c}\text { Number of } \\
\text { items }\end{array}$ & $\begin{array}{c}\text { Cronbach's } \\
\text { Alpha }\end{array}$ \\
\hline $\begin{array}{l}\text { Littering } \\
\text { Attitude }\end{array}$ & 24 & .55 \\
\hline
\end{tabular}

The questionnaire items were separated into positively and negatively worded as described in Table 4. The data were analysed using frequency and descriptive statistics. The frequency analysis is used to describe the demographic of respondents namely; gender, age, and origin state. The descriptive statistics are generated to identify the level of littering attitude among the students and the items of littering attitude. The mean score interpretation used is constructed by Nunnnaly (1997), as displayed in Table 2.

Table 2: Mean score interpretation for behaviour construct towards environment care

\begin{tabular}{|c|c|}
\hline Mean score (\%) & Interpretation of mean score \\
\hline $1.00-2.00$ & Low \\
\hline $2.01-3.00$ & Moderate low \\
\hline $3.01-4.00$ & Moderate high \\
\hline $4.01-5.00$ & High \\
\hline
\end{tabular}

Source: Nunnally (1997)

\section{Findings and Discussions}

Table 3: Frequency of Demographic

\begin{tabular}{|l|l|l|}
\hline Demographic Items & $\mathrm{n}$ & $(\%)$ \\
\hline
\end{tabular}


INTERNATIONAL JOURNAL OF ACADEMIC RESEARCH IN BUSINESS AND SOCIAL SCIENCES Vol. 11, No. 11, 2021, E-ISSN: 2222-6990 @ 2021 HRMARS

\begin{tabular}{|c|c|c|}
\hline Gender & & \\
\hline Male & 19 & 13.7 \\
\hline Female & 120 & 86.3 \\
\hline Age & 137 & 98.6 \\
\hline $18-21$ & 1 & 0.7 \\
\hline $22-25$ & 1 & 0.7 \\
\hline $26-29$ & & \\
\hline Origin State & 1 & $0.7 \%$ \\
\hline Johor & 1 & $0.7 \%$ \\
\hline Kedah & 1 & $0.7 \%$ \\
\hline Kelantan & 3 & $2.1 \%$ \\
\hline $\begin{array}{l}\text { Wilayah Persekutuan } \\
\text { Kuala Lumpur }\end{array}$ & & $43.9 \%$ \\
\hline Pahang & 61 & $10.8 \%$ \\
\hline Perak & 15 & $41.0 \%$ \\
\hline Selangor & 57 & \\
\hline
\end{tabular}

Note. no. of respondents $=139$

Table 3 represents the demographic profile of the respondents. The respondents were $86.3 \%$ (120) female and $13.7 \%$ (19) male. Many of them were aged between 18 to 21 years old $(98.6 \%, n=137)$ and $0.7 \%(n=1)$ aged between 22 to 25 years old and 26 to 29 years old respectively. The respondents were from Semester One, Diploma in Office Management and Technology (BA118). Respondents who live in Pahang is $46 \%(n=64)$, Selangor $38.1 \%(n=$ 53), Perak 10.8\% $(n=15)$, Wilayah Persekutuan Kuala Lumpur $2.1 \%(n=2)$ and $0.7 \%(n=1)$ Kelantan, Negeri Sembilan, Pulau Pinang respectively.

Table 4: Mean for littering attitude

\begin{tabular}{|l|c|c|}
\hline Variable & M & SD \\
\hline Littering Attitude & 3.60 & .28 \\
\hline
\end{tabular}

Note. no. of respondents $=139$

Table 4 shows the level of students' attitude towards littering. The table displays that most of the respondents' littering attitudes were moderately high $(M=3.60, S D=.28)$.

Table 5: Mean for littering attitude's items

\begin{tabular}{|l|c|c|}
\hline Items & M & SD \\
\hline Positively worded: & & \\
\hline
\end{tabular}




\begin{tabular}{|c|c|c|}
\hline I believe littering is a negative habit. & 4.99 & .120 \\
\hline I am not comfortable in a littered surrounding. & 4.91 & .408 \\
\hline I feel uncomfortable whenever I am in a littered environment. & 4.80 & .672 \\
\hline Litter ruins the environment. & 4.79 & .785 \\
\hline Seeing someone littering upsets me. & 4.77 & .569 \\
\hline Seeing litter in drainages upsets me personally. & 4.74 & .652 \\
\hline Litter is unsightly. & 4.58 & .947 \\
\hline $\begin{array}{l}\text { Litter is only considered a problem when it hurts one's personal } \\
\text { well-being. }\end{array}$ & 4.56 & .861 \\
\hline $\begin{array}{l}\text { Any members of the public caught in the act of littering must be } \\
\text { punished. }\end{array}$ & 4.52 & .783 \\
\hline When I see people littering, I feel angry about it. & 4.51 & .765 \\
\hline $\begin{array}{l}\text { When a bin is full, I will carry my litter to the nearest empty litter } \\
\text { bin. }\end{array}$ & 4.49 & .904 \\
\hline If anything, I must admit to a slight dislike of litterers. & 4.14 & .967 \\
\hline $\begin{array}{l}\text { It is my responsibility to report to the appropriate government } \\
\text { agency any person seen littering. }\end{array}$ & 4.06 & .954 \\
\hline $\begin{array}{l}\text { When I see people littering the public places, I will tell them that } \\
\text { public places are extension of personal homes that should not be } \\
\text { littered. }\end{array}$ & 4.00 & 1.022 \\
\hline $\begin{array}{l}\text { If I have enough time or money, I would certainly devote some of it } \\
\text { to the removal of litter in my community. }\end{array}$ & 3.91 & .928 \\
\hline I can participate in removing litter in my community. & 3.85 & 1.103 \\
\hline $\begin{array}{l}\text { Litter is only considered a problem when it hurts the well-being of } \\
\text { others. }\end{array}$ & 2.53 & 1.543 \\
\hline \multicolumn{3}{|l|}{ Negatively worded: } \\
\hline Even though my surrounding is littered, I don't worry much about it. & 1.19 & .64 \\
\hline I believe litter does not hurt anyone. & 1.50 & .98 \\
\hline Throwing small items on the ground is not littering. & 1.61 & 1.12 \\
\hline $\begin{array}{l}\text { When a litter bin is full, it is okay to throw waste on the ground near } \\
\text { the litter bin. }\end{array}$ & 1.68 & 1.05 \\
\hline $\begin{array}{l}\text { I think one should not bother about litter once it is not affecting } \\
\text { ones' life. }\end{array}$ & 1.75 & 1.11 \\
\hline I think time spent in removing litter from public places is wasted. & 1.94 & 1.23 \\
\hline $\begin{array}{l}\text { In the absence of an empty litter bin nearby, it is okay to throw litter } \\
\text { beside a full litter bin. }\end{array}$ & 2.37 & 1.24 \\
\hline
\end{tabular}

Note. no. of respondents $=139$

Table 5 describes the details on the students' attitude toward littering. Most of the students strongly agreed that littering is a negative habit $(M=4.99, S D=.12)$. They also felt uncomfortable in littered surroundings $(M=4.91, S D=.41)$ and whenever they are in $(M=$ $4.80, S D=.672)$. Furthermore, they agreed that litter ruined the environment $(M=4.79, S D=$ .79) and felt upset when seeing someone littering $(M=4.77, S D=.57)$. For them, personally seeing someone litters into the drainage also made them upset $(M=4.74, S D=.65)$. 
Besides, further analysis discovered that the respondents were moderately high to agree that they will talk to the litterers who litter in public places that it is not a good attitude $(M=4.00$, $S D=1.02)$. Some of them agreed to devote their money in removing waste around their living areas $(M=3.91, S D=.93)$ and participate in removing the waste $(M=3.85, S D=1.10)$. For many of them, littering is only considered a problem when it hurts the well-being of others $(M=2.53, S D=1.54)$, which is at a moderate low level. Furthermore, it was a moderate result to some students that, when the absence of an empty litter bin nearby, it is okay to throw litter beside a full litter bin $(M=2.37, S D=1.24)$. As mentioned by Zuraida Kamarudin in the Sun Daily (NA, 2019), although the facilities have been adequately provided for them, approximately, $60 \%$ of the 32 million Malaysian population still fails to throw their garbage into trash bins, and Malaysian communities have not cultivated the habit of disposing of their garbage properly, which should be addressed in efforts to make the country clean.

\section{Conclusion}

The level of littering attitude among Semester One students from Diploma in Office Management and Technology (BA118), in Universiti Teknologi MARA, Pahang Branch was moderately high. This finding is correlatively in line with Asmui et al (2019). They reported that although the level of university students' awareness on the issue of waste disposal was very high, yet, their attitudes in waste disposal are still a concern, as they did not reach the middle of the scale. Othman (2012) in her study on the practice of waste disposal systems in an institution of higher learning has found that the level of students' awareness of the waste disposal practice is low, similar to Asmui et al (2016). Asmui et al (2016) further clarified their finding was correlated with a study conducted by Abdul Latif et al (2013) in which although consumer awareness and concern about waste problems are constantly increasing, participation in recycling is still relatively low. Through environmental education, it is hoped that society, particularly younger people, will be able to understand the important relationship between human and environmental resources (Mohamad, 2014; Asmui et al, 2016) and preserve the nature. In addition, based on previous research by Singh et al (2021), the study found that all three dimensions, attitude, subjective norms, and self-efficacy, have a substantial impact on the intention to engage in anti-littering conduct. Subjective to the norms have the greatest influence on intention, followed by attitude.

Moreover, younger generations will be affected by environmental problems arising from present actions, so they need to be provided with accurate environmental knowledge and skills to develop sustainable solutions (Adomssent et al., 2007; Bradley et al., 1999; Oguz et al., 2010; Vicente-Molina et al, 2013). Students understood that the pervasive attitude of littering causes inconvenience to anyone and anywhere. They also agreed that disposing garbage everywhere has impacts on the environment and lives on Earth. Besides, they were disappointed to see people dumping garbage everywhere, as well as saddened to see drains, ditches, and rivers clogged with garbage. As a result, we anticipate that this younger generation will generate and implement solutions to the littering problem.

Despite their anti-littering stance, these students were found to be relatively low in their level of reprimanding litterers. They were also quite calculative in spending their own money to contribute to garbage disposal work as well as participating in community activities in their neighbourhoods. This is caused by their reliance on garbage disposal operators appointed by the Municipal Council at their residential areas. This result contradicted a study on littering 
habits in Nablus, Palestine, that measured the perception and opinion of residents toward littering and littering practices. It was found that the majority of interviewees shared the perception of street cleanliness as a shared responsibility between citizens and local municipalities, and that $48 \%$ of them were willing to participate as a volunteer to clean the streets within a public campaign (Arafat et al., 2007; Torky, 2017). It was also discovered that the majority of interviewees indicated that one of the factors that would help to hinder people from littering was by enhancing 'moral and religious convictions' because of Islam (Arafat et al., 2007; Torky, 2017).

The students considered the attitude of throwing garbage will be a problem if it makes other people's lives difficult. However, they believed that it's acceptable to throw garbage on the side of a garbage can that is already full of garbage because there are no empty garbage bins nearby. Unlike Japan's youth, since childhood they have been taught to value the environment. They hid candy wrappers in their pockets until they came across a trash can. Meanwhile, Asmui et al (2019) reported that the littering facility provided is found to give high influences to students' good behavior in littering, followed by their awareness and campaign activities. Hence, the finding is consistent with the previous study which mentioned that there was not enough supply of trash bin in their areas, thus resulting in overloaded trash around the existing bins (Harris, 1995; Asmui et al, 2016).

This study's findings extended beyond previous studies' findings, contributing to current knowledge about social littering among university students. To begin, the findings add to the empirical study on subjective norms and attitudes among students toward social littering variables. Second, this study discovered that littering attitudes have evolved into social littering as a result of the involvement of littering effects on the environment and humans, indicating the need for more research in this area. Furthermore, conducting more research in this field may contribute to improved environmental hygiene in the present and future. Littering is not a new problem, and action by universities and governments to address the consequences of social littering is critical.

\section{Recommendations and Limitations}

The contradictory results found in this study suggest that deeper research is needed. The objective of this study to analyse students' attitudes toward littering and to determine their level of attitudes toward littering is achieved. Based on the findings of this study, as for future research, it is recommended for researchers to conduct a study on campus student's actual attitudes related to littering by using interview or observation methods. Moreover, future research can also include the institution administrators as respondents to get their views regarding this littering issue. Future studies may also investigate the influence of knowledge or environmental communication materials on littering behaviour. Besides, other discoveries can also be done to determine the factors that contribute the most to student littering knowledge, for example awareness campaigns, littering knowledge and garbage disposal operators.

Before these findings are generalised, several limitations should be considered. First of all, the subsamples were collected at a single university in a single Malaysian state. As a result, the results cannot represent Malaysia as a whole because they may not reflect different situations that may exist in other states. Second, because the sample was drawn from a single programme at a Malaysian university, generalisation to other programmes at the same 
university may be difficult, and future research will be needed to ensure that the findings can be applied to other university branches with different socioeconomic characteristics. Furthermore, the dependent variable - littering attitude - is measured via a single construct. Hence, it might be interesting to expand this study by including other constructs of littering attitude.

\section{References}

Abdul Latif, S., Omar, M. S., Bidin, Y. H., \& Awang, Z. (2013). Analyzing the effect of situational factor on recycling behavior in determining the quality of life. J ASIAN Behavioral Studies, 3(8), 37-46.

Adomssent, M., Godemann, J., \& Michelsen, G. (2007). Transferability of approaches to sustainable development at universities as a challenge. Internation Journal Sustain Higher Education, 8(4), 385-402.

Ahmad, R. (2021). The Menace of Littering and How to Solve It. https://www.ecomena.org/littering

Arafat, H. A., Khatib, A., Daoud, R., \& Shwahneh, H. (2007). Influence of socioeconomic factors on street litter generation in the Middle East: Effects of education level, age, and type of residence. Waste Management \& Research, 25(4), 363-370.

Asmui, M., Mohd Zaki, S., Syed Wahid, S. N, Mohd Mokhtar, N., \& Harith, S. S. (2016). Association between litterers' profile and littering behavior: A chi-square approach, in Proceeding of $3^{\text {rd }}$ ISM International Statistical Conference 2016,030003.

Asmui, M., Wahid, S. N. S., Mokhtar, N. M., and Harith, S. (2016). Islam dan konsep "hijau": Hubungan antara sikap membuang sampah dan tahap kesedaran di kalangan pelajar institut pengajian tinggi awam, Konferensi Akademik 2016, Universiti Teknologi MARA, Pahang Branch, 15-20.

Asmuni, S., Khalili, J. M., \& Zain, Z. M. (2012). Sustainable consumption practices of students in an urban setting: a case in Selangor. Procedia e Social Behaviour Science, 36, 716-722.

Bautista, P. R. (2019). Level of awareness and practices on solid waste management (SWM) among college students. Journal of Biodiversity and Environmental Sciences (JBES), 14(1), 131-138.

Bradley, J. C., Waliczek, T. M., \& Zajicek, J. M. (1999). Relationship between environmental knowledge and environmental attitude of high school students. Joural of Environment Education, 30, 17-21.

Carmi, N. (2019). On social distress, littering and nature conservation: The case of Jisr AZarka, Coastal Management, 47 (4), 347-361. doi: 10.1080/08920753.2019.1598223

Chaerunnissa, F., Putri, S., Nursakinah, L., Arjuna, F., \& Ratna, D. (2019). Waste Separation Behavior Among University Students. 3rd International Conference on Intervention and Applied Psychology (ICIAP 2019) and the 4th Universitas Indonesia Psychology Symposium for Undergraduate Research (UIPSUR 2019). https://doi.org/10.2991/assehr.k.201125.034.

Cordano, M., Welcomer, S., Scherer, R., Pradenas, L., \& Parada, V. (2010). Understanding cultural differences in the antecedents of pro-environmental behaviour: a comparative analysis of business students in the United States and Chile. Journal Environment Education, 41 (4), 224-238.

Debrah, J. K., Vidal, D. G., \& Dinis, M. A. P. (2021). Raising awareness on solid waste management through formal education for sustainability: A developing countries evidence review. Recycling, 6(6). https://doi.org/10.3390/ recycling6010006 
Estebsari, F., Taghdisi, M. H., Kandi, Z. R., \& Hosseini, A. F. (2017). The effect of students 'role on parents' performance on waste disposal in Maragheh, Savad-I Salamat (Journal of Health Literacy), 2(2), 107-116. https://doaj.org/article/b33a282a5dc84b3bb5d33c771a9a00be

Ewert, A., \& Baker, D. (2001). Standing for where you sit: and exploratory analysis of the relationship between academic major and environment beliefs. Environment and Behaviour, 33, 687-707.

Hansmann, R., \& Scholz, R. (2003). A two-step informational strategy for reducing littering behaviour at a cinema. Environment and Behaviour, 35 (6), 752-762.

Harris, J. R. (1995). Where is the child's environment? A group socialization theory of development, Psychological Review, 102(3), 458.

Ibrahim, H., Mariapan, M., Lin, E. L. A., \& Bidin, S. (2021). Environmental concern, attitude and intention in understanding student's anti-littering behavior using structural equation modeling. Sustainability. 13, 4301. https://doi.org/10.3390/su13084301.

Janmaimool, P., \& Khajohnmanee, S. (2019). Roles of environmental system knowledge in promoting university students' environmental attitudes and pro-environmental behaviors. Sustainability, 11, 4270.

Lizzio, A., Wilson, K., \& Simons, R. (2002). University students' perceptions of the learning environment and academic outcomes: Implications for theory and practice. Student Higher Education, 27, 27-52.

Mohamad, N. (2014). Penglibatan dalam aktiviti kitar semula kertas terpakai dalam kalangan pelajar Fakulti Pendidikan Teknikal dan Vokasional, Universiti Tun Hussein Onn Malaysia, Penganugerahan ljazah Sarjana Pendidikan Teknik dan Vokasional, Fakulti Pendidikan Teknikal dan Vokasional, Universiti Tun Hussien Onn Malaysia, 1-41.

Mokhtar, I. L. (2013). Need to Act on Rubbish Now. New Straits Times, 4.

Nunnally, J. C. (1997). The Study of Change Evaluation Research: Principle Conserning Measurement Experimental Design and Analysis. In E. L. DIm. Struening, \& M. Guttentag (Eds.), Handbook of Evaluation Research. Beverly Hills: Sage.

Oguz, D., Çakci, I., \& Kavas, S. (2010). Environmental awareness of university students in Ankara, Turkey. Africa Journal Agriculture Res. 5, 2629-2636.

Ojedokun, O. (2011). Attitude towards littering as a mediator of the relationship between personality attributes and responsible environmental behavior. Waste Management, 31, 2601-2611.

Ojedokun, O. (2015). The Littering Attitude Scale (LAS): Development and structural validation using data from an indigenous (Nigerian) sample. Management of Environmental Quality An International Journal, 26. https://doi.org/10.1108/MEQ-12-2014-0175.

Othman, F. H. (2012). Amalan Pembuangan Sampah Dalam Kalangan Pensyarah, Pelajar dan Pekerja Kafeteria di Institut Pendidikan Guru Kampus Pendidikan Islam. http://ipgktb.edu.my/lestari/ipglestari/kertas_lestari2012/Fazida\%20binti\%20Haji\%20 O thman.pdf. Accessed 3 November 2016.

Rice, G. (2006). Pro-environmental Behavior in Egypt: Is there a Role for Islamic Environmental Ethics? Journal of Business Ethics, 65(4), 373-390.

Singh J., \& Kaur R. (2021). Influencing the intention to adopt anti-littering behavior: An approach with modified TPB model. Social Marketing Quarterly, 27(2), 117-132. doi:10.1177/15245004211013333 
Sultana, N., Hossen, S., \& Khatun, R. (2017). Assessment of Environmental Knowledge and Attitude of Secondary Level Students of Tangail, Bangladesh. International Journal Res. Environment Sciences, 3, 41-46.

Synodinos, N. E. (1990). Environmental attitudes and knowledge: A comparison of marketing and business students with other groups. Journal of Business Res. 20 (2), 161-170.

Torky, N. (2017). Changing littering behavior among university students in Egypt: Integration of community readiness and community-based social marketing. Master's thesis, the American University in Cairo. AUC Knowledge Fountain.

Vicente-Molina, M. A., Fernández-Sáinz, A., \& Izagirre-Olaizola, J. (2013). Environmental knowledge and other variables affecting pro-environmental behaviour: comparison of university students from emerging and advanced countries, Journal of Cleaner Production, 61, 130-138.

Yatim, N. (2020). Masyarakat Ulang Sikap Suka Buang Sampah Merata-rata. Sinar Harian. https://www.sinarharian.com.my/article/89987/EDISI/Terengganu/Masyarakat-ulangsikap-suka-buang-sampah-merata. 